\title{
The movement of pyruvate, lactate and lactate dehydrogenase into rabbit oviductal fluid
}

\author{
H. J. Leese and Sue Aldridge \\ Department of Biology, University of York, York YOI 5DD, U.K.
}

\begin{abstract}
Summary. Pyruvate, lactate and lactate dehydrogenase appeared linearly in $2 \mathrm{ml}$ $0.9 \% \mathrm{NaCl}$ recirculated through the rabbit oviduct for $4 \mathrm{~h}$ in vivo. In oviducts from rabbits injected 3 days previously with 100 i.u. hCG, the rate of appearance of all three constituents was considerably reduced. It is considered unlikely that the lactate dehydrogenase secreted brings about the interconversion of pyruvate and lactate in the oviduct lumen.
\end{abstract}

\section{Introduction}

Pyruvic acid, lactic acid and lactate dehydrogenase (LDH: EC 1.1.1.27) are components of oviductal fluid in a number of species (Hamner \& Fox, 1969; Hamner, 1973; Bracket \& Mastroianni, 1974) and may be of importance to the metabolism of spermatozoa and preimplantation embryos (Biggers \& Stern, 1973; Kane \& Buckley, 1977; Storey \& Kayne, 1978). Although oviductal fluid is thought to be formed by a combination of the transudation of serum constitutents, and secretion by the endosalpinx, little is known about the details of these processes. Leese \& Jeffries (1977) examined the appearance of glucose in fluid recirculated through the lumen of the rabbit oviduct for $4 \mathrm{~h}$ in vivo and obtained evidence that the glucose moved by facilitated diffusion. We have now used the same technique to follow the movements of pyruvate, lactate and LDH into rabbit oviductal fluid.

\section{Materials and Methods}

New Zealand White rabbits $(3-4 \mathrm{~kg}$ ) were used in all the experiments. They were anaesthetized with $35 \mathrm{mg}$ pentobarbitone sodium (Sagatal: May \& Baker Ltd, Dagenham) $/ \mathrm{kg}$ body weight and kept on a warm tray to assist in maintaining body temperature. In some experiments, ovulation was induced by i.v. injection of 100 i.u. hCG (Pregnyl: Organon Laboratories Ltd, Morden, Surrey). The procedure was similar to that described previously (Leese \& Jeffries, 1977) except that the oviducts were cannulated at their uterine and fimbriated ends with glass cannulae (i.d. $0.6 \mathrm{~mm}$, o.d. $1.2 \mathrm{~mm}$ and i.d. $1.0 \mathrm{~mm}$, o.d. $2.0 \mathrm{~mm}$ respectively) instead of vinyl tubing. The perfusion medium was $2 \mathrm{ml} 0.9 \%(\mathrm{w} / \mathrm{v}) \mathrm{NaCl}$, contained in a water-jacketed vessel at $37^{\circ} \mathrm{C}$ which was withdrawn via a peristaltic pump (Gilson) at a rate of $50 \mu \mathrm{l} / \mathrm{min}$. The medium entered the oviduct at its uterine end, and after leaving at the fimbriated end was returned to the reservoir. Vinyl tubing (i.d. $0.63 \mathrm{~mm}$, o.d. $1.4 \mathrm{~mm}$ : Portex Ltd, Hythe, Kent) was used to connect the various parts of the perfusion circuit.

Serial samples $(50 \mu \mathrm{l})$ of medium for pyruvate and lactate analysis were deproteinized with $6 \%(\mathrm{w} / \mathrm{v}) \mathrm{HClO}_{4}$ and the supernatants were neutralized with $30 \%(\mathrm{w} / \mathrm{v}) \mathrm{K}_{2} \mathrm{CO}_{3}$. After $4 \mathrm{~h}$ a sample of blood was withdrawn from the heart and the plasma was deproteinized and neutralized in a similar manner. The 50- $\mu \mathrm{l}$ samples of perfusion medium for LDH assay were used directly. The lactic acid content of the extracts was measured by the automated method of Leese \& Bronk (1972) in which lactate is converted to pyruvate with NAD and LDH in an alkaline glycine- 
hydrazine buffer at $\mathrm{pH} 9.5$, and the resulting NADH is measured fluorometrically. Lactate standards were used in the range $0.01-0.05 \mathrm{~mm}$. Pyruvic acid was also measured with the Autoanalyzer system by exploiting the reverse reaction in which pyruvate is converted to lactate, and $\mathrm{NADH}$ to NAD. In this case the buffer was triethanolamine hydrochloride, $\mathrm{pH} 7 \cdot 6$, containing $3 \mu \mathrm{M}-\mathrm{NADH}$. In both methods the LDH concentration was $30 \mathrm{i} . \mathrm{u} . / \mathrm{ml}$. All enzymes and coenzymes were obtained from Boehringer Corporation (London) Ltd, Lewes, East Sussex. The pyruvate method was extremely sensitive and full scale deflection on the recorder could be obtained with $5 \mu \mathrm{M}$ substrate. Lactic acid dehydrogenase activity was measured by the manual method of Bergmeyer \& Bernt (1974), in which pyruvate is converted to lactate with the

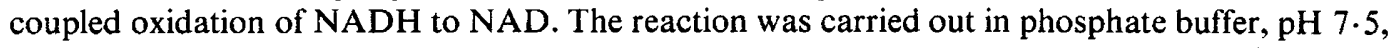
containing $0.6 \mathrm{~mm}$-pyruvate and $0.18 \mathrm{~mm}-\mathrm{NADH}$. When the sample of perfusion medium to be assayed for LDH was added, there was a linear drop in optical density at $340 \mathrm{~nm}$, and the rate of the reaction was unchanged when the pyruvate and NADH concentrations were doubled, indicating that optimal enzyme rates were being measured. The LDH activity was expressed as nmol NADH converted/min. In all the experiments, the data from the left and right oviducts were pooled, since no consistent differences were ever detected between them. Values are given as mean \pm s.e.m.

\section{Results}

The appearance of pyruvate in the medium circulated through the rabbit oviduct is shown in Text-fig. 1(a), and that of lactate in Text-fig. 1(b). Pyruvate and lactate appeared linearly to reach $4 \mathrm{~h}$ concentrations of $0.16 \pm 0.03 \mathrm{mM}(n=9)$ and $0.83 \pm 0.12 \mathrm{~mm}(n=9)$ respectively, i.e. a ratio of concentrations of about $1: 5$. The average $4 \mathrm{~h}$ plasma concentrations were $0.61 \pm$ $0.17 \mathrm{~mm}$-pyruvate and $5.87 \pm 1.15 \mathrm{~mm}$-lactate, i.e. a ratio of almost $1: 10$. If the pyruvate and lactate appearing in the oviductal fluid were derived solely from the plasma, this would imply that pyruvate was moving across the oviduct faster, relative to its starting concentration, than lactate.
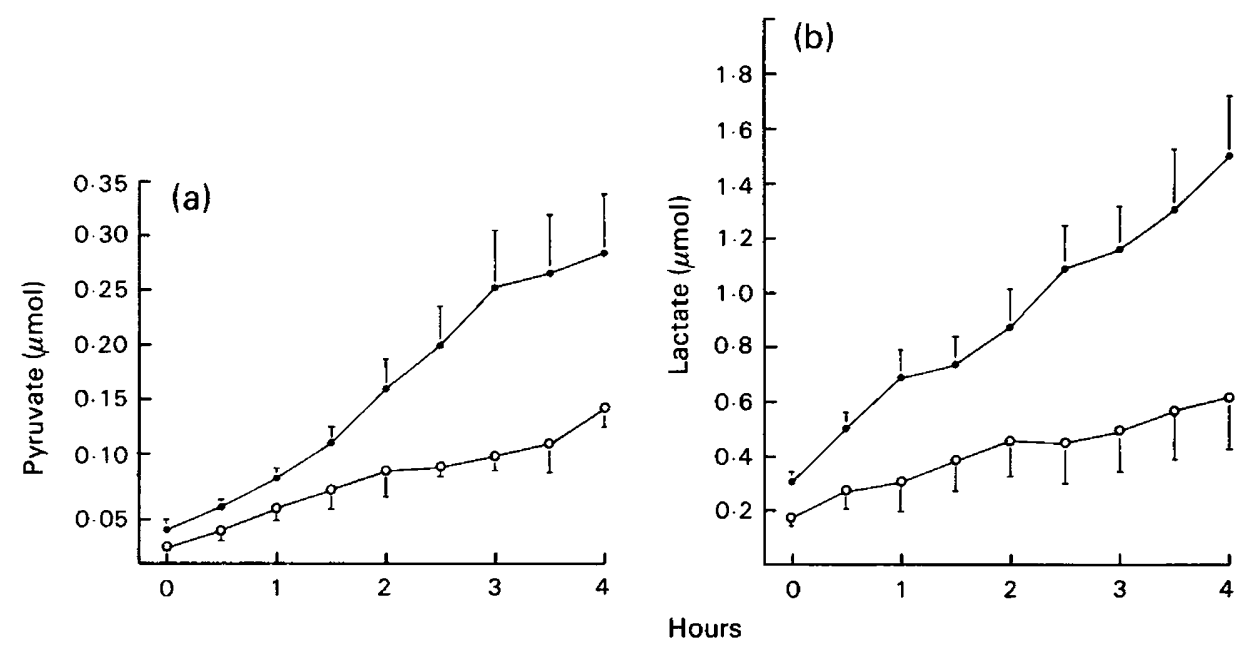

Text-fig. 1. The time course of appearance of (a) pyruvate and (b) lactate in fluid circulating through the oviducts of control $(0)$ and hCG-injected $(0)$ rabbits in vivo. Control values are mean \pm s.e.m. of at least 8 (a) or 9 (b) oviducts; hCG-injected values are mean \pm s.e.m. of at least 5 oviducts $(a$ and $b)$. The traces do not start from the origin because pyruvate and lactate have not been completely rinsed out from the oviducts at the start. 
LDH appearance in the perfused oviduct over $3 \mathrm{~h}$ is shown in Table 1. The LDH appeared linearly and the concentration reached after $3 \mathrm{~h}$ was approximately $50 \%$ of that in the plasma.

The rabbits injected with hCG were examined 3 days later when most of the ova are within the isthmus (Greenwald, 1961; Gupta, Karkun \& Kar, 1970). As shown in Text-fig. 1, the rates of pyruvate and lactate appearance in the oviductal fluid were considerably reduced, the final levels being only $50 \%$ and $41 \%$ respectively of the controls. There was no detectable appearance of LDH in 4 oviducts studied 3 days after hCG injection, and 4-h increases of only 25 and 33 units in 2 others.

Table 1. The time course of lactate dehydrogenase appearance in fluid circulating through the rabbit oviduct in vivo

\begin{tabular}{lccc}
\hline Time $(\mathrm{h})$ & 1 & 2 & 3 \\
$\begin{array}{l}\text { LDH (nmol NADH converted/ } \\
\text { min) }\end{array}$ & $16.4 \pm 5.1$ & $33.9 \pm 6.0$ & $54.6 \pm 9.9$ \\
\hline
\end{tabular}

Values are mean \pm s.e.m. of 7 oviducts.

If the pyruvate and lactate appearing in oviductal fluid were interconverted by the LDH secreted, this would presumably require NAD and/or NADH. To check for the presence of this reaction two experiments were carried out. In the first a sample of fluid from a 4-h perfusion on a normal rabbit oviduct was added to a cuvette containing pyruvate and LDH. In the second, a sample of 4-h fluid was placed on its own in a cuvette. In each case the optical density at $340 \mathrm{~nm}$ remained completely steady, suggesting that no detectable $\mathrm{NAD}(\mathrm{H})$-mediated interconversion of pyruvate and lactate was taking place.

\section{Discussion}

We have shown that the appearance of pyruvate, lactate and LDH in rabbit oviductal fluid may be studied over the relatively short period of $4 \mathrm{~h}$. This will enable a better estimate to be made of the rates and biochemical mechanisms underlying the secretion of these constituents than has hitherto been possible.

The present experiments provide only limited information on the origin of the pyruvate, lactate and LDH appearing in oviductal fluid. They could be derived from the plasma, from the cells of the endosalpinx (Mastroianni, Winternitz \& Lowi, 1958; Gibson \& Masters, 1970; Gupta et al., 1970; Varma \& Talmar, 1975; Misra, Gupta \& Karkun, 1977), or from both sources.

The appearance of pyruvate, lactate and LDH was reduced 3 days after hCG administration. The same was true for glucose (H. J. Leese \& S. Aldridge, unpublished). Holmdahl \& Mastroianni (1965) showed that the concentrations of pyruvate and lactate in tubal fluid collected under refrigerated conditions were significantly increased after ovulation while that of tubal protein was not, and this finding for protein has been confirmed by Oliphant, Bowling, Eng, Keen \& Randall (1978). However, the volume of oviductal fluid is markedly reduced in rabbits by the 3rd day of pseudopregnancy or following mating (Riddick, 1975; Oliphant et al., 1978) and, since the present method was not designed to detect changes in the volume of the oviductal fluid, the effect of ovulation was to bring about a reduction in the absolute amounts of pyruvate, lactate and LDH appearing.

While it is easy to ascribe a physiological role for the pyruvate and lactate in oviductal fluid in terms of sperm, ovum and preimplantation embryo metabolism, it is difficult to understand the significance of LDH as an enzyme, rather than as a protein, in the absence of NAD and NADH. 
Oliphant et al. (1978) showed that the rate of movement of serum proteins into rabbit oviductal fluid was inversely proportional to their molecular weight, and it is possible that LDH is simply following the same pattern. However, Biggers \& Stern (1973) have commented on the difficulty of explaining the presence of high LDH levels in the early mouse embryo, and it is not inconceivable that this enzyme may have some unsuspected role in the early events of reproduction.

We are grateful to the Medical Research Council for a research grant.

\section{References}

Bergmeyer, H.-U. \& Bernt, E. (1974) Lactate dehydrogenase. In Methods of Enzymatic Analysis, 2nd English edn, Vol. 2, pp. 574-579. Ed. H.-U. Bergmeyer. Academic Press, New York.

Biggers, J.D. \& Stern, S. (1973) Metabolism of the preimplantation mammalian embryo.. Adv. Reprod. Physiol. 6, 1-59.

Brackett, B.G. \& Mastroianni, L., Jr. (1974) Composition of oviducal fluid. In The Oviduct and its Functions, pp. 133-150. Eds A. D. Johnson \& C. W. Foley. Academic Press, New York.

Gibson, C. \& Masters, C.J. (1970) Oviducal lactate dehydrogenase. J. Reprod. Fert. 22, 157-159.

Greenwald, G.S. (1961) A study of the transport of ova through the rabbit oviduct. Fert. Steril. 12, 80-95.

Gupta, D.N., Karkun, J. \& Kar, A.B. (1970) Biochemical changes in different parts of the rabbit Fallopian tube during passage of ova. Am. J. Obstet. Gynec. 106, 833-837.

Hamner, C.E. (1973) Oviducal fluid-composition and physiology. In Handbook of Physiology, Section 7, Vol. 2, Part 2, pp. 141-170. Eds. R. O. Greep \& E. B. Astwood. American Physiological Society, Washington, D.C.

Hamner, C.E. \& Fox, S.B. (1969) Biochemistry of oviductal secretions. In The Mammalian Oviduct, pp. 333-355. Eds E. S. E. Hafez \& R. J. Blandau. University of Chicago Press.

Holmdahl, R.H. \& Mastroianni, L., Jr (1965) Continuous collection of rabbit oviduct secretions at low temperature. Fert. Steril. 16, 587-595.

Kane, M.T. \& Buckley, N.J. (1977) The effects of inhibitors of energy metabolism on the growth of one-cell rabbit ova to blastocysts in vitro. J. Reprod. Fert. 48, 261-266.

Leese, H.J. \& Bronk, J.R. (1972) Automated fluorometric analysis of micromolar quantities of ATP, glucose and lactic acid. Analyt. Biochem. 45, 211-221.

Leese, H.J. \& Jeffries, K.S. (1977) Evidence for the facilitated diffusion of glucose into rabbit oviductal fluid. J. Reprod. Fert. 51, 93-97.

Mastroianni, L., Jr, Winternitz, W.W. \& Lowi, N.P. (1958) The in vitro metabolism of the human endosalpinx. Fert. Steril. 9, 500-509.

Misra, D., Gupta, D.N. \& Karkun, J.N. (1977) Conrtribution of lactic acid by the ampullary and isthmic parts of rabbit fallopian tube under altered hormonal conditions. Acta endocr., Copenh. 85, $665-672$.

Oliphant, G., Bowling, A., Eng, L.A., Keen, S. \& Randall, P.A. (1978) The permeability of rabbit oviduct to proteins present in the serum. Biol. Reprod. 18, 516-520.

Riddick, D.H. (1975) The composition of rabbit oviducal fluid collected continuously throughout gestation. $J$. Reprod. Fert. 43, 563-566.

Storey, B.T. \& Kayne, F.J. (1978) Energy metabolism of spermatozoa. VII. Interactions between lactate, pyruvate and malate as oxidative substrates for rabbit sperm mitochondria. Biol. Reprod. 18, 527536.

Varma, S.K. \& Talmar, G.P. (1975) Nature of the stimulus of the copulation-induced rise in lactic dehydrogenase activity in the rabbit oviduct. $J$. Reprod. Fert. 45, 505-508. 